\title{
Alterations in muscular enzymes of horses competing long-distance endurance rides under tropical climate
}

[Alterações em enzimas musculares de cavalos em competições de enduro de longa distância em clima tropical]

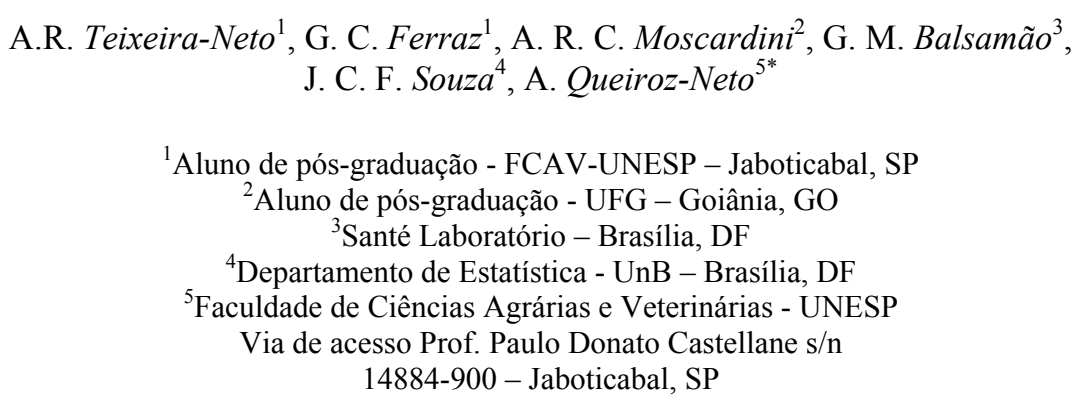

\begin{abstract}
This study tried to monitor the alterations of muscle enzymes activity - creatinokinase (CK), lactate dehydrogenase (LDH), and aspartate aminotransferase (AST) - in a group of horses that participated of 70 and $100 \mathrm{~km}$ distance rides in five competitions of an annual endurance championship under tropical climate. Pre ride levels (U/l) were $245.13 \pm 9.84$ for $\mathrm{CK}, 496.61 \pm 14.76$ for $\mathrm{LDH}$, and $328.95 \pm 8.65$ for AST. When compared to these levels, the results revealed a significant decrease in all enzymes activities in the first moment of the rides. Peak levels, significantly different, were reached, immediately after rides by CK (413.591 \pm 50.75$) ; 24$ hours post rides by LDH (628.61 \pm 33.30$)$; and 48 hours after rides by AST (389.89 \pm 16.96$)$. Monitoring of recovery period revealed different behavior among enzymes activities with CK values returning to pre ride values $(279.61 \pm 23.05) 24$ hours post rides, while LDH and AST values returned to pre ride values $(505.25 \pm 33.78$ and $359.35 \pm 24.90$, respectively) 72 hours post rides. These data revealed different alterations in concentration of muscular enzymes in endurance horses directly related to the duration of the effort.
\end{abstract}

Keywords: horse, endurance, enzymes, muscle

\section{RESUMO}

Estudaram-se as alterações de atividade das enzimas musculares creatino quinase (CK), lactato desidrogenase (LDH) e aspartato aminotransferase (AST) em um grupo de cavalos que utilizados em provas de enduro de 70 e $100 \mathrm{~km}$ de distância, em cinco competições. Os valores (U/l) basais (antes da

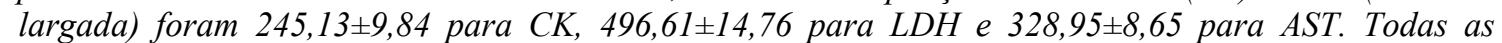
atividades das enzimas decresceram no primeiro momento das provas $(\sim 30 \mathrm{~km})$. Valores de pico, significativamente diferentes, foram alcançados para CK $(413,59 \pm 50,75)$ imediatamente após $70 \mathrm{~km}$ de

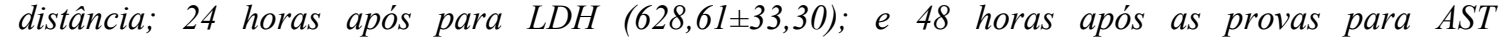
$(389,89 \pm 16,96)$. A monitoração do periodo de recuperação revelou diferente comportamento entre as concentrações enzimáticas com CK retornando aos valores basais 24 horas pós-provas $(279,61 \pm 23,05)$.

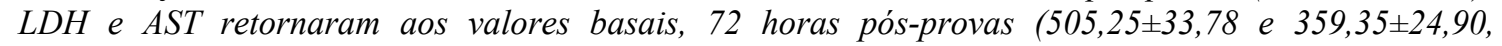
respectivamente). Os dados obtidos revelaram diferentes alterações na concentração de enzimas musculares de cavalos de enduro, diretamente relacionadas com a duração do esforço.

Palavras-chave: cavalo, enduro, enzimas, músculo

Recebido em 5 de junho de 2007

Aceito em 25 de março de 2008

*Autor para correspondência (corresponding author)

E-mail: aqueiroz@fcav.unesp.br 


\section{INTRODUCTION}

Today, competitive endurance riding is one of the emerging equestrian sports in the world. Horses are submitted to long-lasting efforts and a well prepared organism is imperative to deal with this exercise. One of the systems that directly suffer with this effort is the muscular apparatus. Permanent workload leads this system to constant damage that can be accessed by laboratorial determinations of some plasma constituents (Overgaard et al., 2004).

The activities of the enzymes are usually low in serum or plasma because they are normally located within healthy cells. Elevations of enzymes activities in serum may also occur in association of increased cell permeability (Cardinet, 1997).

The release of cytoplasmic enzymes, including creatine kinase (CK), aspartate transaminase (AST), and L-lactate dehydrogenase (LDH), is considered to be a suitable parameter for the evaluation of muscle injury during exercise (Da Cás et al., 2000). CK is among the most important muscle-specific enzymes and it is present in tissues as specific isoenzyme. The determination of that isoenzyme is clinically used as a diagnostic tool in musculoskeletal disease. However, an increase in the total serum activities of $\mathrm{CK}$ and $\mathrm{LDH}$ has been observed in healthy horses following strenuous exercise. Such events have been related to an increased skeletal muscle membrane leakage (Siciliano et al., 1995). CK is rapidly released from muscle after injury, with a peak activity at 4-12 hours after a muscle insult and removed from blood within $2 \mathrm{~h}\left(\mathrm{~T}_{1 / 2}\right)$. In muscle, this enzyme functions in making ATP available for contraction by the phosphorylation of ADP from creatine phosphate (Cardinet, 1997). By contrast, AST and LDH are found in most soft tissues, with peak concentrations after 24 hours and a much longer half-life being seven days (Clarkson and Ebbeling, 1988; Harris, 1998). Thus, exercise of long duration leads to large elevations of these enzymes in plasma (Overgaard et al., 2004).

Enzyme activity in plasma is used as an indicator of muscle leakage during exercise. Enzymes most useful in evaluating muscular leakage include CK and AST. Their values can vary for a number of reasons, including alteration of membrane permeability, cell necrosis, impaired enzyme clearance, and increased enzyme synthesis (Harris, 1998). Plasma CK and AST activities may increase during exercise without observation of clinical signs or histological detection of changes in muscle cell structure (Valberg et al., 1993; Câmara e Silva et al., 2007)

The aim of the present study was to monitor the degree of muscle permeability by determining variations on its enzymes activity (CK, LDH, and AST) during and after five 70 and $100 \mathrm{~km}$ distance endurance rides, under tropical climate.

\section{MATERIAL AND METHODS}

The experiment was carried out with a group of horses during 70 and $100 \mathrm{~km}$ distance endurance rides, in a regional championship divided in five competitions throughout the year 2004 (May, July, September, October, and December), under tropical climate. The resultant curves totalized 91 observations in the beginning of rides. All horses were Arabian, with three to four years of training program, and came from different stables and training centers.

In the rides, the distance ( \pm SEM) of each ring was $30.81 \pm 1.66\left(\mathrm{M}_{1}\right), 27.8 \pm 1.82\left(\mathrm{M}_{2}\right)$, and $20.55 \pm 1.62\left(\mathrm{M}_{3}\right)$ for the first, second, and third one, respectively. The horses that completed $70 \mathrm{~km}$ distance rides had an average speed of $12.2 \pm 0.25 \mathrm{~km} / \mathrm{h}$. In the $100 \mathrm{~km}$ rides, they completed the effort with an average speed of $11.6 \pm 0.3 \mathrm{~km} / \mathrm{h}$, with an extra ring of $17.62 \pm 1.86 \mathrm{~km}$ distance.

Jugular punctures were done before, during, and after the rides. The first sample was always done from two to five hours before the beginning of each ride, and this moment was considered $\mathrm{M}_{0}$, related to basal values. After the completion of each ring, blood samples were also collected and these moments were considered $\mathrm{M}_{1}, \mathrm{M}_{2}, \mathrm{M}_{3}$, and $\mathrm{M}_{4}$ for the $100 \mathrm{~km}$ rides, for which an extra ring was added. Moments three and four refer to the end of 70 and $100 \mathrm{~km}$ rides, respectively. Blood samples were colleted 24, 48, and 72 hours after each ride with the purpose to monitor recovery time of horses in their stables. Blood samples were collected into evacuated glass collection 
tubes $^{1}$ with a coagulant factor, chilled in water with ice, and centrifuged ( 5 minutes, 3000rpm) to separate serum samples from blood cells. The activities of serum enzymes were determined through a kinetic assay in ultraviolet with lab kits $^{22}$.

The vet check gate consisted in a restrict area where a complete clinical examination of all horses was done before the beginning of the endurance rides, just after the arrival of each ring and at the end of the rides. This was supposed to be the crucial point of endurance rides when official veterinarians could eliminate any horse, if the animal did not show enough physical condition to continue the task. This clinical exam started when a horse was presented by the rider, for heart frequency determination. Heart rate was considered to maintain the horse in the ride when no more than 60 beats per minute (bpm) was measured. After approved in heart beats, the horse was conduced for a complete physical exam with special attention to heart and respiratory rates, hydration status, capillary refill time, mucous colorness, intestinal movements, muscular aches, and general condition. After that, the horse had to trot for 40 meters (forward and backward) and a visual exam was performed to check if the horse was lame or not. If it passed throughout this vet check gate, a rest period of 40 minutes was allowed before the continuation of the ride. Horses that were disqualified, heart beat higher than $60 \mathrm{bpm}$, were also monitored throughout the rides until the point of elimination. Lame horses were not included in this study.

The results obtained during the five competitions of the championship were plotted in a curve with five moments $\left(\mathrm{M}_{0}\right.$ to $\left.\mathrm{M}_{4}\right)$ during rides, including pre ride (basal) values. Post ride values were also plotted after the curve break and were related to 24, 48, and 72 hours. All obtained data revealed significant differences throughout the rides when compared to basal values (pre ride) by the $\mathrm{t}$ student test $(\mathrm{P}<5 \%)$. Data were expressed as mean values \pm their standard errors. Pearson's coeficient (r) between horses that finished 70 and $100 \mathrm{~km}$ rides was made to check the correlation between these groups.

\footnotetext{
${ }^{1}$ Vacuette ${ }^{\circledR}$ - Americana, SP - Brazil

${ }^{2}$ Labtest ${ }^{\circledR}$ - Belo Horizonte, MG - Brazil
}

\section{RESULTS}

The activity of CK in 70 and $100 \mathrm{~km}$ rides are shown in Table 1. A high correlation $(r=0.93)$ between these curves allowed to plot all data in only one curve (Fig. 1). The number of samples obtained throughout the experiment was not always the same due the elimination of some horses and processing problems. The resultant curve revealed a significantly decrease in $M_{1}$ when compared to pre ride values and a significant increase, peaking at $\mathrm{M}_{3}$. In $\mathrm{M}_{4}$, it remained increased and returned to basal values 24 hours after rides. It was noticed a decrease, significant different from the basal values, 72 hours after rides.

LDH activity values in 70 and $100 \mathrm{~km}$ rides are also shown in Table 1, with a correlation (r) of 0.77 . Putting the results of both 70 and $100 \mathrm{~km}$ rides together, Fig. 2 was constructed. It can be seen that a significant decrease occurred in $\mathrm{M}_{1}$ and returned to basal levels in the subsequent moments $\left(\mathrm{M}_{2}\right.$ and $\left.\mathrm{M}_{3}\right)$. A significant increase was revealed at the end of $100 \mathrm{~km}$ rides $\left(\mathrm{M}_{4}\right)$ remaining increased 24 to 48 hours post rides, when returned to pre ride values after 72 hours.

AST activity values during 70 and $100 \mathrm{~km}$ rides are shown in Table 1 and since they were strongly correlated $(\mathrm{r}=0.89)$, they were plotted together in Fig. 3. When compared to basal values, the resultant curve revealed a significant decrease in $M_{1}, M_{2}$, and $M_{3}$, returning to pre ride values in $M_{4}$. Post ride values remained increasing at 24 hours, revealed a significant difference at 48 hours, and finally returned to pre ride values 72 hours after the exercise. During rides, the study also monitored eliminated horses on each point of disqualification; but the values of all enzyme activities at those points did not reveal any difference comparing to those from horses that successfully completed the rides.

\section{DISCUSSION}

Oxygen free radicals lead to loss of membrane integrity and cellular functions by the lipid peroxidation of polyunsaturated lipids followed by the inactivation of enzymes and increase of ionized calcium $\left(\mathrm{Ca}^{2+}\right)$, which in turn could activate various degradative pathways in working muscle cells (Braughler, 1988). It may explain the significant decrease of all enzymes activities that occurred in $\mathrm{M}_{1}$ of rides. 


\section{Teixeira-Neto et al.}

Table 1. Values of enzymes activities of horses before $\left(M_{0}\right)$, during $\left(M_{1}\right.$ to $\left.M_{4}\right)$, and after (recovery period, 24 to 72 hours) 70 and $100 \mathrm{~km}$ distance endurance rides

\begin{tabular}{|c|c|c|c|c|c|c|c|c|c|c|}
\hline $\begin{array}{c}\text { Enzyme } \\
(\mathrm{U} / 1)\end{array}$ & $\begin{array}{l}\text { Distance } \\
(\mathrm{km})\end{array}$ & $\mathrm{M}_{0}$ & $\mathrm{M}_{1}$ & $\mathrm{M}_{2}$ & $\mathrm{M}_{3}$ & $\mathrm{M}_{4}$ & $24 \mathrm{~h}$ & $48 \mathrm{~h}$ & $72 \mathrm{~h}$ & $\mathrm{r}$ \\
\hline \multirow{6}{*}{ CK } & 70 & 259.29 & 201.95 & 266.02 & 436.15 & - & 335.28 & 322.56 & 240.46 & \multirow{6}{*}{0.93} \\
\hline & & \pm 13.46 & \pm 50.70 & \pm 46.80 & \pm 83.91 & & \pm 44.20 & \pm 67.75 & \pm 25.20 & \\
\hline & $\mathrm{n}$ & 51 & 34 & 25 & 19 & & 15 & 19 & 17 & \\
\hline & 100 & 227.07 & 176.74 & 305.00 & 480.62 & 382.26 & 300.53 & 264.86 & 215.04 & \\
\hline & & \pm 14.06 & \pm 26.52 & \pm 53.39 & \pm 87.63 & \pm 47.25 & \pm 45.55 & \pm 24.69 & \pm 26.78 & \\
\hline & $\mathrm{n}$ & 40 & 30 & 19 & 16 & 20 & 12 & 20 & 19 & \\
\hline \multirow{6}{*}{$\mathrm{LDH}$} & 70 & 535.20 & 449.60 & 524.20 & 532.93 & - & 725.49 & 629.36 & 489.51 & \multirow{6}{*}{0.77} \\
\hline & & \pm 18.78 & \pm 67.00 & \pm 35.30 & \pm 60.70 & & \pm 95.35 & \pm 60.38 & \pm 62.31 & \\
\hline & $\mathrm{n}$ & 51 & 36 & 26 & 22 & & 14 & 15 & 14 & \\
\hline & 100 & 448.36 & 345.54 & 542.67 & 604.92 & 588.76 & 683.73 & 762.12 & 560.97 & \\
\hline & & \pm 21.39 & \pm 21.37 & \pm 56.44 & \pm 99.61 & \pm 37.24 & \pm 52.08 & \pm 78.58 & \pm 52.77 & \\
\hline & $\mathrm{n}$ & 40 & 30 & 19 & 16 & 20 & 12 & 19 & 18 & \\
\hline \multirow{6}{*}{ AST } & 70 & 327.64 & 230.04 & 257.66 & 290.09 & - & 335.71 & 383.96 & 380.71 & \multirow{6}{*}{0.89} \\
\hline & & \pm 11.93 & \pm 14.80 & \pm 16.51 & \pm 16.96 & & \pm 20.97 & \pm 24.54 & \pm 39.68 & \\
\hline & $\mathrm{n}$ & 51 & 32 & 25 & 22 & & 17 & 21 & 22 & \\
\hline & 100 & 330.63 & 248.59 & 254.97 & 285.18 & 292.94 & 424.83 & 424.85 & 377.74 & \\
\hline & & \pm 12.66 & \pm 13.91 & \pm 18.63 & \pm 21.98 & \pm 12.58 & \pm 33.56 & \pm 25.81 & \pm 34.01 & \\
\hline & $\mathrm{n}$ & 40 & 32 & 19 & 16 & 17 & 12 & 17 & 17 & \\
\hline
\end{tabular}

CK: creatine kinase, $\mathrm{LDH}$ : lactate dehydrogenase, AST: aspartate amino transferase.

$\mathrm{M}_{0}$ : start point; $\mathrm{M}_{1}: \sim 30 \mathrm{~km} ; \mathrm{M}_{2}: \sim 55 \mathrm{~km} ; \mathrm{M}_{3}: \sim 70 \mathrm{~km} ; \mathrm{M}_{4}: \sim 100 \mathrm{~km}$ distance. 24,48 and $72 \mathrm{hs}$ refer to recovery period after rides.

$\mathrm{n}$ : the number of samples in each moment of rides. r: Pearson's correlation coefficient between 70 and $100 \mathrm{~km}$ rides. Data are expressed as means value $\pm \operatorname{SEM}(\mathrm{P}<5 \%)$.

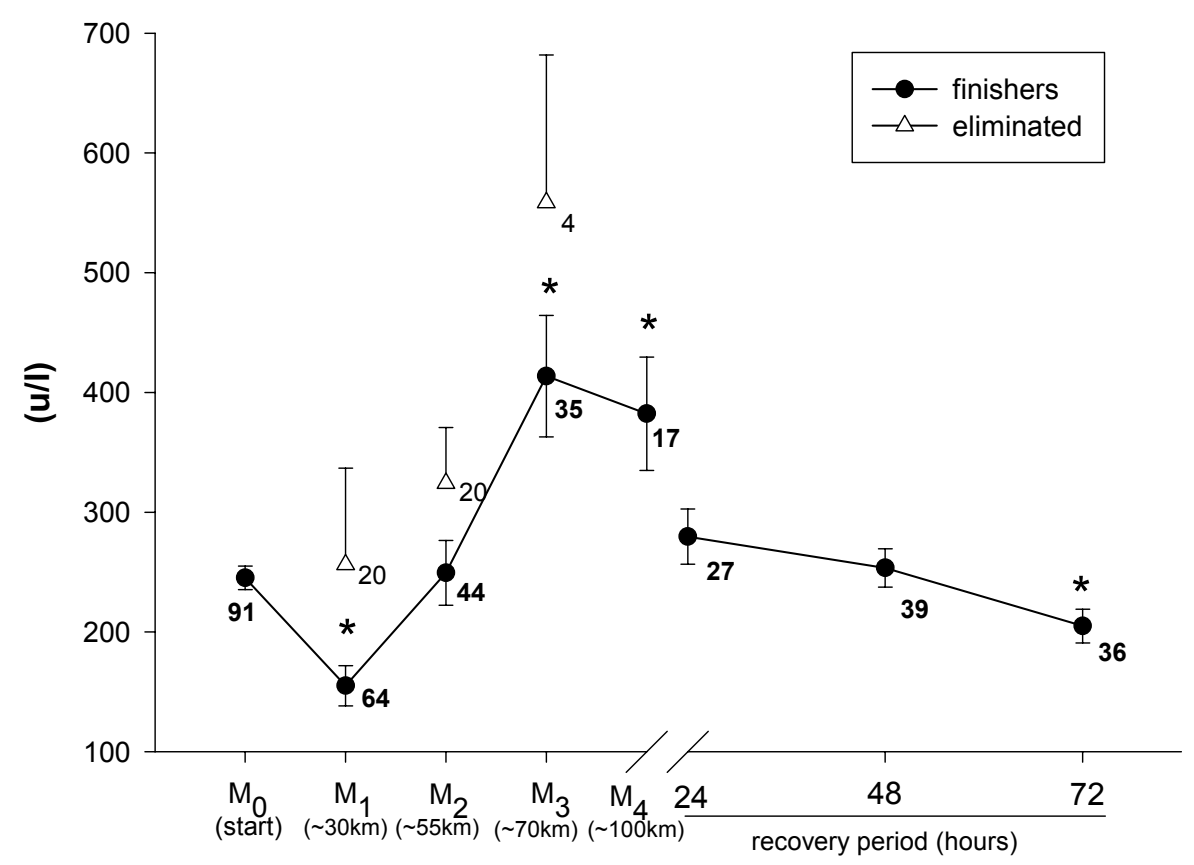

Figure 1. Creatine kinase $(C K)$ activity before $\left(M_{0}\right)$, during $\left(M_{1}\right.$ to $\left.M_{4}\right)$, and after (recovery period, 24 to 72 hours) 70 and $100 \mathrm{~km}$ distance endurance rides. Data are expressed as mean values $\pm \mathrm{SEM}(\mathrm{P}<5 \%)$. *reveals significant difference between each moment when compared to pre ride values $\left(\mathrm{M}_{0}\right)$. Numbers beside each symbol indicate total of samples in that moment. 


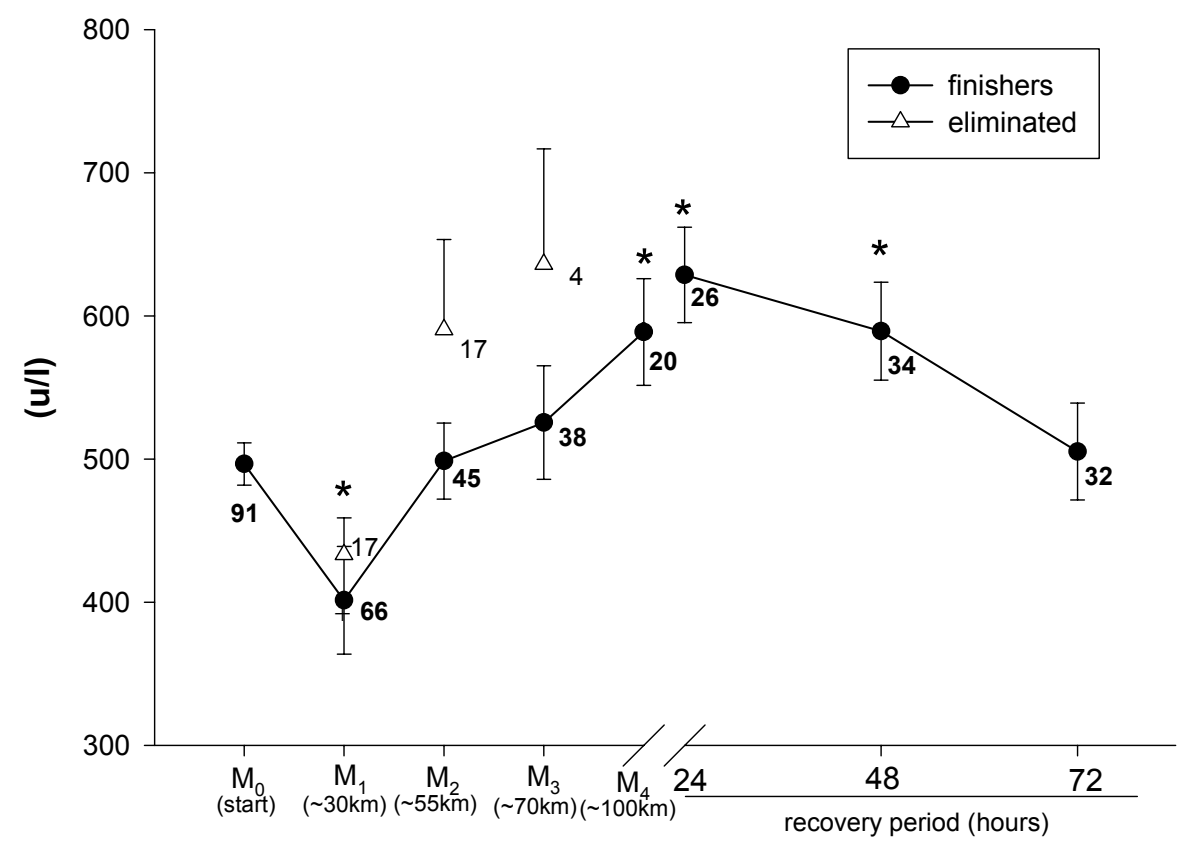

Figure 2. Lactate dehydrogenase (LDH) activity before $\left(\mathrm{M}_{0}\right)$, during $\left(\mathrm{M}_{1}\right.$ to $\left.\mathrm{M}_{4}\right)$, and after (recovery period, 24 to 72 hours) 70 and $100 \mathrm{~km}$ distance endurance rides. Data are expressed as mean values \pm SEM $(\mathrm{P}<5 \%)$. *reveals significant difference between each moment when compared to pre ride values $\left(\mathrm{M}_{0}\right)$. Numbers besides each symbol indicate total of samples in that moment.

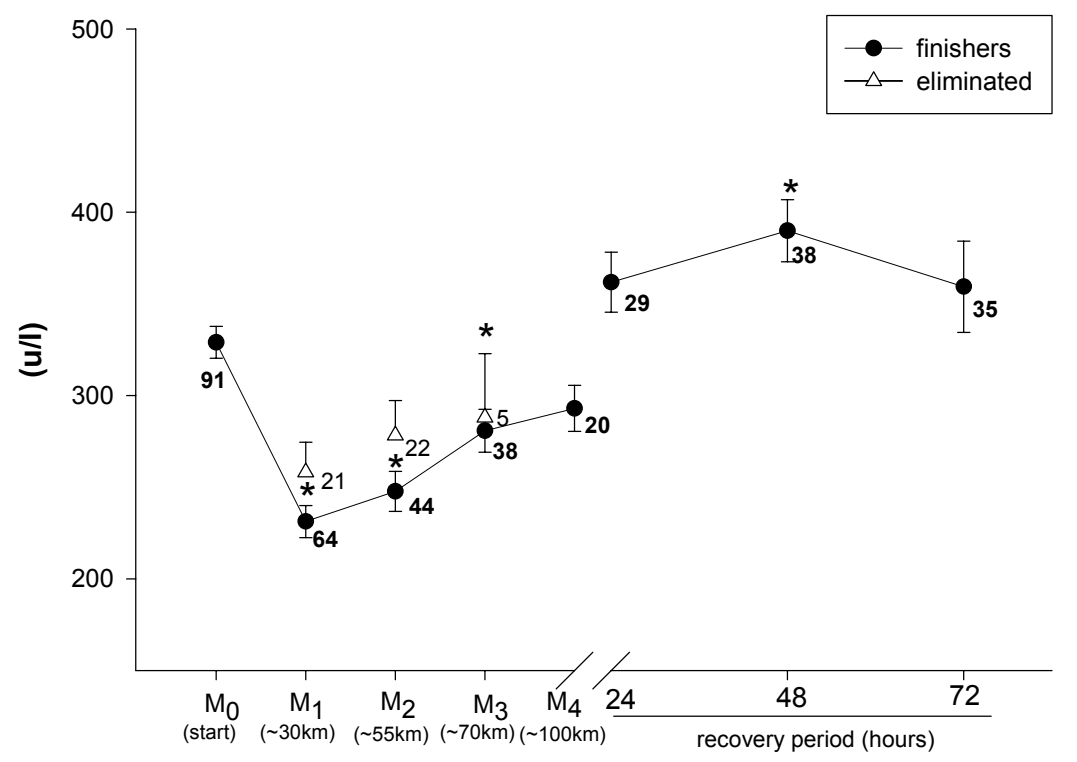

Figure 3. Aspartate aminotransferase (AST) activity before $\left(\mathrm{M}_{0}\right)$, during $\left(\mathrm{M}_{1}\right.$ to $\left.\mathrm{M}_{4}\right)$, and after (recovery period, 24 to 72 hours) 70 and $100 \mathrm{~km}$ distance endurance rides. Data are expressed as mean values \pm SEM (P $<5 \%)$. *reveals significant difference between each moment when compared to pre ride values $\left(\mathrm{M}_{0}\right)$. Numbers besides each symbol indicate total of samples in that moment. 
Increases in plasma CK, AST, and LDH activities (Harris, 1998) have been seen in response to exercise. These increases are believed to relate either to overt damage or to a change in the muscle fiber membrane causing a transient increase in permeability (Boyd, 1985). However, physiological increases have been also shown to occur without any tissue destruction (Valberg et al., 1993).

During rides, it was noticed that, in $\mathrm{M}_{2}$, the activity of $\mathrm{CK}$ and $\mathrm{LDH}$ had elevated, as related by Armstrong (1986), that pointed out that increases in plasma levels of enzymes such as $\mathrm{CK}$ and LDH after exercise are caused by leakage from damaged muscle fibers in exercise.

The values of $\mathrm{CK}$ in plasma after exercise depend largely on the duration and kind of the exercise (Overgaard et al., 2004; Câmara e Silva et al., 2007). It was also noticed for CK activity that it reached peak levels in $\mathrm{M}_{3}$ and remained increased in $\mathrm{M}_{4}$. These values can confirm the data shown by Hodgson (1985), in which peak levels of CK were proposed to occur from six to 12 hours after the beginning of the exercise. On the contrary, basal values were obtained 24 hours after rides, differing from Ricketts (2004) who pointed that $\mathrm{CK}$ activity returns to baseline from three to four days, assuming that no further myopathy occurs.

LDH activity was similar to $\mathrm{CK}$ behavior; however, peak values were just obtained in the first 24 hours post ride, and remained high in the subsequent moment (48 hours), returning to basal values just 72 hours post exercises. These results revealed a later onset of peak values of this enzyme, as shown by other studies (Hodgson, 1985; Clarkson and Ebbeling, 1988; Harris, 1998).

Data obtained for AST activity revealed a similar behavior (a significant decrease in $\mathrm{M}_{1}$ ) remained decreased for two subsequent moments $\left(\mathrm{M}_{2}\right.$ and $\mathrm{M}_{3}$ ). By the way, in $\mathrm{M}_{4}$, these values increased to pre ride values until 24 hours and significantly increased 48 hours post rides, returning to basal values 72 hours post endurance rides. These data also corroborate with Ricketts (2004), who showed that AST levels peak at 24-48 hours, after myopathy, but revealed a different behavior in the recovery period to the same study that showed baseline values 10 to 21 days, assuming that no further damage occurred (Rickets, 2004). Elevated plasma AST and CK activities demonstrated muscle cell damage and leakage of these enzymes into the circulatory system (Hargreaves et al., 2002).

The enzymes activities of eliminated horses did not reveal any significant alteration throughout the rides when compared to those from horses that successfully completed the tasks in the same moment of disqualification.

The main problem in the evaluation of plasma muscular enzymes values is defining the normal increase in enzyme activity in response to a specific exercise regimen. Given that strenuous exercise can result in increased CK, AST, and LDH plasma activities without any sign of muscle damage or stiffness, it is rather difficult to differentiate between borderline functional or physiological and pathological changes (Muñoz et al., 2002).

The data obtained in this study could also indicate higher enzymes activities, or muscle alterations, in a long-lasting endurance exercise when compared to previous studies under same climate conditions, but shorter distances (Teixeira-Neto et al., 2004) and lighter efforts (Da Cás et al., 2000; Santos et al., 2001), revealing the relation between muscular alterations and the duration and intensity of an endurance effort. The interpretation of these data allows a better understanding of physiologic adaptations of athletic horses submitted to endurance exercise under tropical climate and also shows the time spent to wash up their body of some exercise catabolites.

\section{CONCLUSIONS}

Monitoring of muscular enzymes activities can provide a critical evaluation of the level of membranes permeability caused by the endurance exercise. Different behavior of enzymes activities throughout endurance efforts, that are directly related to the duration of it, was shown and can be used as a tool to follow the amount of muscle alterations and the recovery time for horses submitted to this exercise. 


\section{REFERENCES}

ARMSTRONG, R.B. Muscle damage and endurance events. Sports Med., v.3, p.370-381, 1986.

BOYD, J.W. The mechanisms relating to increases in plasma enzymes and isoenzymes in diseases of animals. Vet. Clin. Pathol., v.12, p.9$25,1985$.

BRAUGHLER, J.M. Calcium and lipid peroxidation. In: HALIWELL, B. (Ed.) Oxygen radicals and tissue injury. Bethesda: Allen Press, 1988. p.94-104.

CÂMARA E SILVA, I.A.; DIAS, R.V.C.; SOTO-BLANCO, B. Determinação das atividades séricas de creatinina quinase, lactato desidrogenase e aspartato aminotransferase em eqüinos de diferentes categorias de atividade. Arq. Bras. Med. Vet. Zootec., v.59, p.250-252, 2007.

CARDINET III, G.H. Skeletal muscle function, In: KANEKO, J.J.; HARVEY, J.W.; BRUSS, M.L. (Eds.). Clinical biochemistry of domestic animals. 5.ed. New York: Academic, 1997. p.407-440.

CLARKSON, P.M.; EBBELING, C. Investigation of serum creatine kinase variability after muscle damaging exercise. Clin. Sci., v.75, p. 257-261, 1988 .

DA CÁS, E.L.; ROSAURO, A.C.; SILVA, C.A.M. et al. Concentração sérica das enzimas creatinoquinase, aspartato aminotransferase e hidrogenase láctica em eqüinos da raça crioula Cien. Rural, v.30, p.625-629, 2000.

HARGREAVES, B.J.; KRONFELD, D.S.; WALDRON, J.N. et al. Antioxidant status and muscle cell leakage during endurance exercise. Equine Vet. J., v.34, suppl., p.116-121, 2002.

HARRIS, P.A. Muskuloskeletal disease. In: REED, S.M.; BAYLY W.M. (Eds). Equine internal medicine. Philadelphia: W.B. Saunders, 1998. p.375-397.
HODGSON, D.R. Myopathies in athletic horses. Comp. Cont. Educ., v.7, S551-S556, 1985.

MUÑOZ, A.; RIBER, C.; SANTISTEBAN, R. et al. Effect of training duration and exercise on blood-borne substrates, plasma lactate and enzyme concentrations in Andalusian, AngloArabian and Arabian breeds. Equine Exercise Physiology 6. Equine Vet. J., v.34, suppl., p.245$251,2002$.

OVERGAARD, K.; FREDSTED, A.; HYLDAL, A. et al. Effects of running distance and training on $\mathrm{Ca}^{2+}$ content and damage in human muscle. Med. Sci. Sports Exercise, v.36, p.821-829, 2004.

RICKETTS, S.W. Hematologic and biochemical abnormalities in athletic horses In: HINCHCLIFF, K.W.; KANEPS, A.J.; GEOR, R.J. (Eds). Equine sports medicine and surgery. Basic and clinical sciences of the equine athlete. Philadelphia: Saunders, 2004. p.949-966.

SANTOS, S.A.; SILVA, R.A.M.S.; AZEVEDO, J.R.M. et al. Serum electrolyte and total protein alterations in Pantaneiro horse during long distance exercise Arq. Bras. Med. Vet. Zootec., v.53, p.351-357, 2001 .

SICILIANO, P.D.; LAWRENCE， L.M.; DANIELSEN, K. et al. Effect of conditioning and exercise type on serum creatine kinase and aspartate aminotransferase activity. Equine Vet. J., v.18, suppl., p.243-247, 1995.

TEIXEIRA-NETO, A.R.; FERRAZ, G.C.; MATAQUEIRO, M.I. et al. Electrolyte reposition on physiologic variables of horses submitted to 30 and $60 \mathrm{~km}$ endurance rides Cien. Rural, v.34, p.1505-1511, 2004.

VALBERG, S.; JOHNSON, L.; LINDHOLM, A. et al. Muscle histopathology and plasma aspartate aminotransferase, creatine kinase and myoglobin changes with exercise in horses with recurrent exertional rhabdomyolysis. Equine Vet. J., v.25, p.11-16, 1993. 